\title{
Modelling approach for the rainfall erosivity index in sub- humid urban areas in northern Algeria
}

\author{
IMANE TOUAIBIA ${ }^{1}$, NEKKACH ABDERRAHMANE GUENIM ${ }^{1}$ \\ \& BENINA TOUAIBIA ${ }^{2}$ \\ 1 Dept. d'Hydraulique. University, Abou Bakr Bel Kaid Tlemcen, Algérie \\ touaibia_Imane@yahoo.fr \\ 2 Ecole Nationale Supérieure d'Hydraulique, Blida, MVRE, Algérie
}

\begin{abstract}
This work presents an approach for storm water erosivity index modelling in the absence of measurement in an urban area, in a sub-humid climate. In torrential storms, floods, loaded with sediments, obstruct storm water drainage. With the aim of estimating the amount of sediment that can be deposited on a stretch of road, adjacent to the study area, the erosivity index is determined from a count of 744 rain showers recorded over a period of 19 years. The Universal Soil Loss Equation (USLE) of Wischmeier and Smith is applied, where only the index of erosivity is calculated; it is based on the intensity of the rain starting the process of erosion in the basin. Functional relations are required between this factor and the explanatory variables. A power type regression model is reached, making it possible to bring a decision-making aid in absences of measurements.Key words statistical models, specific erosion, sub-humid climate, urban hydrology, USLE
\end{abstract}

\section{INTRODUCTION}

Algeria, like all other Maghreb countries, has a serious problem in the estimation of erosion. It remains among the more erodible countries (Hasbaia et al. 2012). In Algeria, the first measurement of erosion began in 1946 (Medinger 1960, Demmak, 1982) while trying to find a relationship for quantification of solid contributions for different forms of erosion. Unfortunately they encountered a complex problem, as quantification of factors started the processes in the absence of measurement. In urban and extra-urban areas this problem is then more delicate, when we observe an important quantity of sediment deposited on the roads, heads, etc. In agricultural suburban areas where erosion in the aquifer is felt, the process is accelerated by practices factors, and it degrades soil and decreases its fertility. The city of Sidi Rached has seen these problems within sight of the agricultural nature of the area where it is established. The sediments deposited mainly come from an erosion in the aquifer, visible on site (Touaibia 2013).

\section{SITE DESCRIPTION}

The study area extending over 500 ha belongs to the city of Sidi Rached. It is located $80 \mathrm{~km}$ northwest of the capital Algier, in the district of Tipaza. Geographically it overhangs the littoral and the plane of Mitidja. Ten sub-basins extend over a range of $14 \mathrm{~km}$, covering a broad area which belongs to the Wadi Djer catchment, one of the most important rivers in the coastal Algerian basins (ANRH, 2005). These sub-basins pour all their water onto the national road NR67, which is on the border (Fig. 1). Physiographical and hydro-morphometric characteristics are summarized in Table 1. A digital model of the ground (MNT) is established (Fig. 2).

\section{HYDROLOGICAL DATA}

The Sidi Rached area does not have hydrometric stations. However, two rainfall stations are taken into consideration: Sidi Rached, which has annual rainfall and maximum annual days, and Meured dam, located in the same hydro-climatic conditions, which has an important hyetograph registration.

The interannual average rainfall of the Sidi Rached station over the period 1973/1974$2010 / 2011$ is $486 \mathrm{~mm}$, the minimum and the maximum values are 266 and $755 \mathrm{~mm}$, respectively, for the years 1989/1990 and 1984/1985 (Fig. 3). 


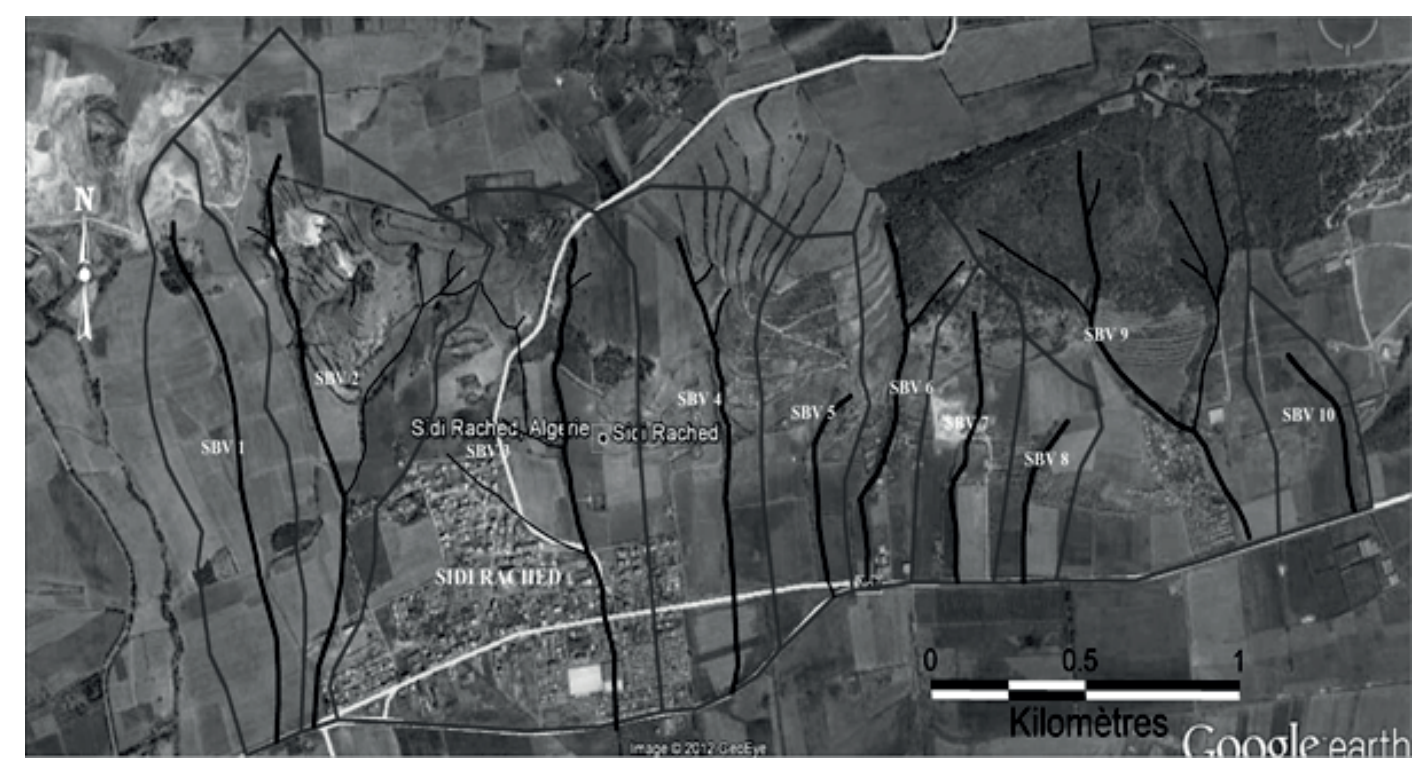

Fig.1 Urban and suburban catchments and rivers: untreated satellite image (Landsat, 2012, Algerie n-32-35).

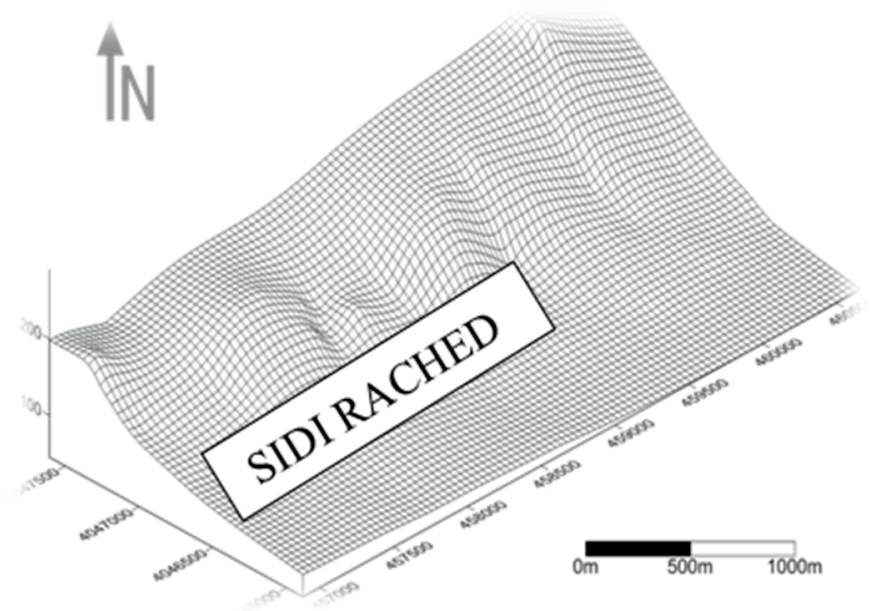

Fig. 2 Sight 3D (MNT) of the study area.

Table 1 Physiographical and hydro-morphometric characteristics of the basins.

\begin{tabular}{llllllllllll}
\hline $\begin{array}{l}\text { Basin } \\
\text { characteristic }\end{array}$ & 1 & 2 & 3 & 4 & 5 & 6 & 7 & 8 & 9 & 10 & $\begin{array}{l}\text { Djer } \\
\text { basin }\end{array}$ \\
\hline $\mathrm{S}\left(\mathrm{km}^{2}\right)$ & 0.5 & 0.8 & 1.1 & 0.6 & 0.3 & 0.3 & 0.2 & 0.1 & 0.9 & 0.2 & 110.9 \\
$\mathrm{P}(\mathrm{km})$ & 3.6 & 4.7 & 4.4 & 3.2 & 2.4 & 2.6 & 2.1 & 1.7 & 4.2 & 1.8 & 52.0 \\
$\mathrm{Kc}$ & 1.5 & 1.5 & 1.2 & 1.2 & 1.2 & 1.4 & 1.2 & 1.3 & 1.3 & 1.3 & 1.4 \\
$\mathrm{H}_{\max }(\mathrm{m})$ & 201 & 205 & 205 & 210 & 212 & 228 & 180 & 140 & 293 & 130 & 740 \\
$\mathrm{H}_{\min }(\mathrm{m})$ & 73 & 69 & 69 & 58 & 64 & 64 & 64 & 64 & 64 & 68 & 50 \\
$\mathrm{H}_{\text {mean }}(\mathrm{m})$ & 107 & 139 & 102 & 113 & 121 & 133 & 103 & 92 & 145 & 90 & 143.5 \\
$\mathrm{I}_{\mathrm{m}}(\mathrm{m} / \mathrm{km})$ & 1.4 & 2.0 & 1.5 & 4.5 & 2.3 & 3.4 & 1.4 & 0.7 & 4.5 & 0.5 & 68 \\
$\mathrm{I}_{\mathrm{g}}(\mathrm{m} / \mathrm{km})$ & 67.7 & 62.4 & 79.9 & 121.5 & 183.0 & 154.5 & 140.8 & 96.9 & 132.3 & 87.2 & 19.6 \\
$\mathrm{~L}_{\mathrm{cp}}(\mathrm{km})$ & 1.4 & 1.6 & 1.4 & 1.2 & 0.6 & 1 & 0.7 & 0.5 & 1.3 & 0.5 & 22.1 \\
$\mathrm{I}_{\mathrm{cp}}(\mathrm{m} / \mathrm{km})$ & 53.9 & 63.9 & 0.8 & 82.3 & 100 & 137.4 & 116.2 & 80.9 & 138.6 & 78.4 & 31.6 \\
$\mathrm{D}_{\mathrm{d}}\left(\mathrm{km} / \mathrm{km}^{2}\right)$ & 2.9 & 3.7 & 2.5 & 2.7 & 2.0 & 4.7 & 3.3 & 3.5 & 3.4 & 3.3 & 10 \\
$\mathrm{~T}_{\mathrm{c}}(\mathrm{h})$ & 0.3 & 0.3 & 1.4 & 0.2 & 0.1 & 0.1 & 0.1 & 0.1 & 0.2 & 0.1 & 10 \\
\hline
\end{tabular}

S: drainage area; P: perimeter; Kc: form index; $\mathrm{H}_{\max }$ : $\max$ altitude; $\mathrm{H}_{\min }$ : min altitude; $\mathrm{H}_{\text {mean }}$ : mean altitude; $\mathrm{I}_{\mathrm{m}}$ : mean basin slope; $\mathrm{I}_{\mathrm{g}}$ : global slope; $\mathrm{I}_{\mathrm{cp}}$ : main river slope; $\mathrm{D}_{\mathrm{d}}$ : drainage density; $\mathrm{T}_{\mathrm{c}}$ : concentration time. 


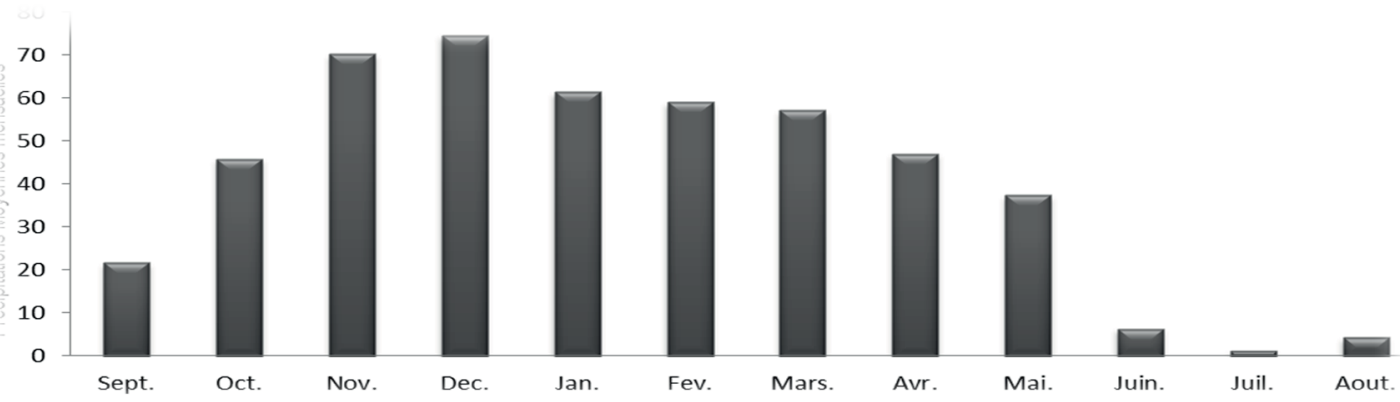

Fig. 3 Annual precipitation of Sidi Rached over the observation period (1973/1974-2010/2011).

\section{Rainfall-runoff erosivity factor}

At the raingauge of the Meured dam, 744 rain showers were recorded and stripped one by one. In order to quantify erosion in the aquifer the Universal Soil Loss Equation (USLE) of Wischmeier and Smith (1978) is applied. While only being based on the hydrological aspect of this equation, only the rainfall aggressiveness is considered and represented by index R, which is dependent on the released energy of the rain in contact with the ground and on its intensity. The index R can be quantified over a given period.

From the point of view of the management and preservation of water and soil, the other factors of the equation have to be necessarily measured, which is not the objective of this work. The zone of study consisted of a clay soil combined with the impact of the rain, and as a result the soil swells and bursts and the processes of erosion start, in particular in the barren area of the basin.

Following the problems of several Algerian areas, as for the lack of storm hyetographs, two approaches are considered which consist of searching functional relations, not only between the erosion index $\mathrm{R}$ and interannual rainfall $\mathrm{P}_{\mathrm{an}}$, but also between the erosion index $\mathrm{R}$ and the maximum intensity $I_{\max }$, in order to estimate the contribution in sediment which can be engendered.

The USLE equation is based on six factors that directly influence the flow of the area and the erosion phenomenon. Only the erosion index is considered in the work:

$$
\mathrm{A}=1.3 \mathrm{RKLSCP}
$$

With A: computed soil loss $\left[\mathrm{t} \cdot \mathrm{ha}^{-1} \mathrm{year}^{-1}\right]$; R: rainfall-runoff erosivity factor; $\mathrm{K}$ : soil erodibility factor; L: slope length factor; S: slope steepness factor; C: cover management factor; P: supporting practices factor.

The erosion index $\mathrm{R}$ characterizes the rainfall aggressiveness, and allows estimation from the storms of the quantity of ground that can be removed from a soil, when all the parameters are not neglected. This index is obtained by adding for considered period $R_{i}$ values characterizing rainy episodes. Generally, the annual average erosion index is calculated from the annual rainfall. Its formulation is as follows:

$$
\mathrm{R}=\mathrm{E}_{\mathrm{g}} \cdot \mathrm{I}_{30 \mathrm{~min}}
$$

with $E_{\mathrm{g}}$ : global kinetic energy of rainfall $\left(\mathrm{m} \mathrm{tha}^{-1}\right) ; \mathrm{I}_{30 \mathrm{mn}}$ : homogeneous maximum intensity rainfall in 30 minute $(\mathrm{s})(\mathrm{cm} / \mathrm{h})$.

\section{Data processing}

The processing consisted of analysis of hyetographs for a determination of the homogeneous intensity of 30 minutes and the maximum intensity observed over 30 minutes. An example of the analysis of hyetograph reconstituted by the storm of 19/09/2001 is given in Fig. 4, while the calculation of $\mathrm{R}$ is presented in Table 2 .

Neglecting the other parameters of the USLE equation (reported to R unit), the erosion index $\mathrm{R}_{\text {USLE }}$ would represent the annual loss in soil, i.e. 55 ( $\mathrm{t} / \mathrm{ha}$ ). 


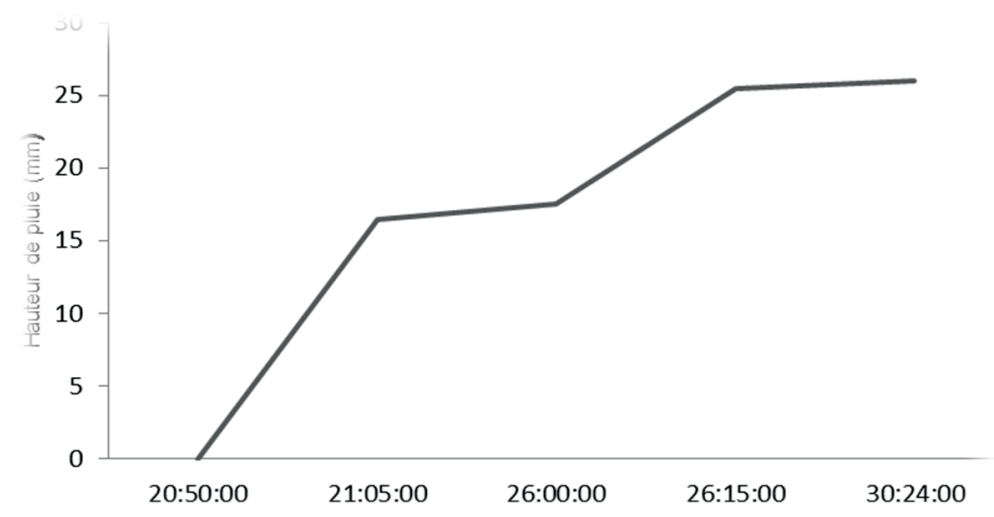

Fig. 4 Hyetograph reconstituted by storm of 19/09/2001.

Table 2 Example of hyetograph analysis.

\begin{tabular}{|c|c|c|c|c|c|c|c|c|c|c|c|}
\hline 1 & $\begin{array}{l}2 \\
h\end{array}$ & $\mathrm{~m}$ & $\mathrm{~S}$ & $\begin{array}{l}3 \\
\mathrm{~mm}\end{array}$ & $\mathrm{~cm}$ & $\begin{array}{l}4 \\
\mathrm{I}_{\mathrm{h}} \\
(\mathrm{cm} / \mathrm{h})\end{array}$ & $\begin{array}{l}5 \\
\mathrm{E}_{\mathrm{u}} \\
\left(\mathrm{m} \cdot \mathrm{t} \cdot \mathrm{ha}^{-1} \cdot \mathrm{cm}^{-1}\right)\end{array}$ & $\begin{array}{l}6 \\
E_{h} \\
\left(m \cdot t \cdot h a^{-1}\right)\end{array}$ & $\begin{array}{l}7 \\
\mathrm{E}_{\mathrm{g}} \\
\left(\mathrm{m} \cdot \mathrm{t} \cdot \mathrm{ha}^{-1}\right)\end{array}$ & $\begin{array}{l}8 \\
\mathrm{I}_{\max 30 \mathrm{mn}} \\
(\mathrm{cm} / \mathrm{h})\end{array}$ & $\begin{array}{l}9 \\
\mathrm{R} \\
\left(\mathrm{m} \cdot \mathrm{t} \cdot \mathrm{m} \cdot \mathrm{ha}^{-1} \cdot \mathrm{h}^{-1}\right)\end{array}$ \\
\hline \multirow[t]{3}{*}{$19 / 09 / 2001$} & \multirow{3}{*}{4} & 15 & 0 & 16.5 & 1.65 & 6.60 & 282.94 & 466.85 & 678.72 & 0.02 & 0.14 \\
\hline & & 55 & 0 & 1 & 0.1 & 0.02 & 59.44 & 5.94 & & & \\
\hline & & 15 & 0 & 8 & 0.8 & 3.20 & 254.96 & 203.97 & & & \\
\hline
\end{tabular}

1. Storm date; 2. Time (h, m, s); 3. Height of water $(\mathrm{mm})$ and $(\mathrm{cm}) ; 4$. Homogeneous intensity $(\mathrm{cm} / \mathrm{h}) ; 5$. Unit energy $\left(\mathrm{m} \cdot \mathrm{t}^{\mathrm{h}} \cdot \mathrm{h}^{-1} \cdot \mathrm{cm}^{-1}\right)$ of fallen water; 6 . Energy of the rain of homogeneous intensity $\left(\mathrm{m} \mathrm{tha}^{-1}\right) ; 7$. Global energy $\left.(\mathrm{m} \mathrm{tha})^{-1}\right)$; 8.Maximum intensity in 30 minutes $(\mathrm{cm} / \mathrm{h}): 9$. Erosion index $\mathrm{R}\left(\mathrm{m} \mathrm{t} \mathrm{m} \mathrm{ha} \mathrm{m}^{-1} \mathrm{~h}^{-1}\right)$.

Table 3 Monthly and annual distribution of the erosion index R for 744 storms registered in the period 1985/1986 to $2005 / 2006$.

\begin{tabular}{ccccccccccccccc}
\hline Year & Sep & Oct & Nov & Dec & Jan & Feb & Mar & Apr & May & Jun & Jul & Aug & $\begin{array}{c}\text { Annual R } \\
\left(\mathrm{m} \cdot \mathrm{t} \cdot \mathrm{m} \cdot \mathrm{ha}^{-1} \cdot \mathrm{year}^{-1}\right)\end{array}$ \\
\hline $1985 / 86$ & - & - & - & - & - & - & - & 0.6 & 0.1 & 0.5 & 14.8 & - & & 16 \\
$1986 / 87$ & 11.1 & 40 & 1.6 & 13.2 & 6.8 & 9.8 & 0.7 & - & - & 1.2 & 0.4 & - & 85 \\
$1987 / 88$ & 3.0 & 0.1 & 1.4 & 3.9 & 0.5 & 0.4 & 0.3 & 0.5 & 2.7 & 1.2 & - & - & & 14 \\
$1988 / 89$ & 3.6 & 5.6 & 0.5 & 4.6 & 6.7 & 0.2 & 14.4 & 7.5 & - & 2.3 & - & 0.1 & 46 \\
$1989 / 90$ & 0.1 & 0.1 & 1.5 & 1.3 & 2.4 & - & 6.8 & 1.7 & 3.7 & - & 0.1 & - & 18 \\
$1990 / 91$ & 0.1 & 0.1 & 5 & 2.6 & 16.0 & 2 & 1.3 & 3.2 & 0.3 & 0.1 & - & - & 31 \\
$1991 / 92$ & - & 83 & 0.1 & 0.1 & 21.6 & 4.9 & 3.4 & 5.5 & 8.3 & 0.3 & 0.2 & - & 127 \\
$1992 / 93$ & - & 6.7 & 3.2 & 7.3 & 0.1 & - & 0.8 & 2.2 & 3.6 & - & - & - & 24 \\
$1993 / 94$ & 0.2 & - & 0.5 & 0.5 & 12.4 & 0.8 & - & 6.2 & 0.1 & - & - & - & 21 \\
$1994 / 95$ & 1.4 & - & 20 & 4.4 & 1.5 & 3.1 & 14.4 & - & - & 0.1 & - & 0.2 & 45 \\
$1995 / 96$ & 41.1 & 0.8 & 1.1 & 0.2 & 1.3 & 1.4 & 0.7 & 5.0 & 0.2 & 4.3 & - & - & 56 \\
$1996 / 97$ & - & - & - & - & - & - & - & 6.8 & - & - & - & - & 7 \\
$1999 / 00$ & - & - & 2.5 & - & - & 63.7 & 3.4 & 1.8 & 3.9 & 0 & 0.0 & 0 & 75 \\
$2000 / 01$ & 2.3 & 14.8 & 6.8 & 1.2 & 12.3 & 1.8 & 0.1 & 10.8 & 2.5 & 0.4 & 0 & 0 & 53 \\
$2001 / 02$ & 1.5 & 22.0 & 12.6 & 3.7 & 2.6 & 4.2 & 4.3 & 43 & 0.8 & 0 & 2.8 & 2 & 100 \\
$2002 / 03$ & 12.8 & 4.6 & 22.0 & 16.2 & 8.1 & 6.9 & 1.5 & 4.8 & 13.2 & 0.0 & 0.4 & 0 & 90 \\
$2003 / 04$ & 1.6 & 15.1 & 9.2 & 5.1 & 3.5 & 3.2 & 6.2 & 10.9 & 20.3 & 0.6 & 0.4 & 3.8 & 80 \\
$2004 / 05$ & 24.4 & 1.4 & 9.6 & 10.1 & 9.1 & 17.4 & - & - & 0.4 & 0.8 & 0 & 0.0 & 73 \\
$2005 / 06$ & 0.1 & 5 & 1.7 & 0.1 & 12.3 & 4.7 & 30.8 & 0.6 & 31.7 & 0.6 & 0 & 0.0 & 87 \\
$\mathrm{R}_{\text {mean }}$ & & & & & & & & & & & & & 55 \\
\hline
\end{tabular}

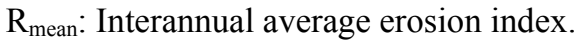

From a hydrological point of view, the soil losses that widely exceed the annual acceptable threshold of $10 \mathrm{t} / \mathrm{ha}$ (Touaibia 2000) confirm the existence of an important erosion in topsoil, concluding that the catchment is affected (Tixeront 1960). 
The search for a functional relation between the erosion index $R$ and annual rainfall $R=f\left(P_{a n}\right)$ has been effected for five regressive models: linear, logarithmic, power, exponential and parabolic models. In view of the coefficient of determination, the power model between the erosion index and the annual rainfall $R=f\left(P_{\text {an }}\right)$ is retained (Fig. 5).

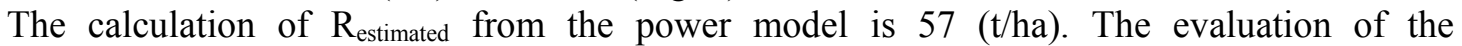
representativeness of power model of the relation $R=f\left(\mathrm{P}_{a n}\right)$, is made by considering the error committed in the estimation of the erosion index R. This error is given in equation (3).

$$
\text { Error }(\%)=\left(\frac{R_{U S L E}-R_{\text {estimated }}}{R_{U S L E}}\right) \cdot 100
$$

The calculated error is 3\%, is low and thus acceptable, the power model of the relation between the erosion index of rainfall $\mathrm{R}$ and the cumulated annual precipitation can be considered in the estimation of soil losses from the annual storms in urban and suburban areas in the absence of hydrometric data and where the erosion of topsoil is dominant.

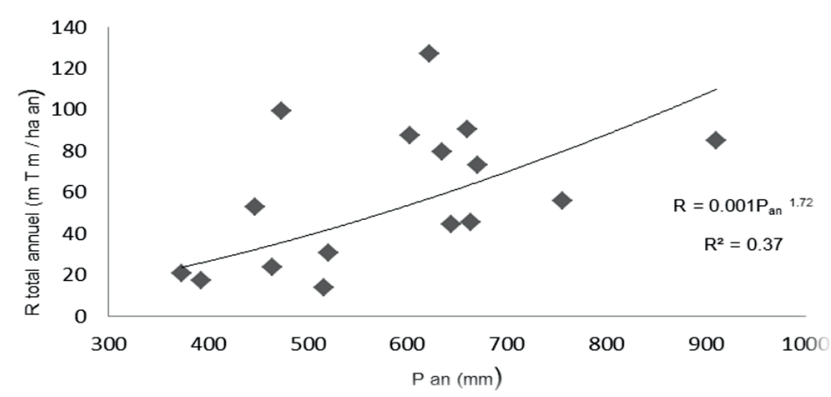

Fig. 5 Power model for relationship $\mathrm{R}=\mathrm{f}\left(\mathrm{P}_{\mathrm{an}}\right)$.

\section{CONCLUSION}

The main objective of this work is the quantification of topsoil erosion in the city of Sidi Rached by applying the formula of Wischmeier, mainly focusing attention on the erosion index of rainfall R. This parameter has been calculated for a set of 744 storms. The results showed that annual erosion in the basin is very important (about $55 \mathrm{t} / \mathrm{ha}$ ). The study area is classified as a zone with excessive blanket erosion. A functional relationship of the power type between the erosion index $\mathrm{R}$ and the annual rainfall $\mathrm{P}_{\text {an }}$ provides satisfactory results, justified by an error estimated as about $3 \%$. This power model can be considered in the estimation of the soil loss from the annual rainfall in urban and suburban parts of the study area.

\section{REFERENCES}

ANRH (2005) Agence Nationale des Ressources Hydraulique. Carte du réseau hydro climatologique et de la surveillance de la qualité des eaux, Ech 1:500 000

Demmak, A. (1982) Contribution à l'étude de l'érosion et de transport solide en Algérie septentrionale. Thèse de doctoratIngénieur, Univ. Paris, France, 323

Hasbaia, M. Hedjazi, A. and Benayada, L. (2012) Variabilité de l'érosion hydrique dans le bassin du Hodna: cas du sous-bassin versant de l'oued elham. Revue Mar. Sci. Agron. Vét. 1, 28-32.

Medinger, J. M. (1960) Transport solide des oueds algériens. Annuaire hydrologique de l'Algérie (années 50-59), Alger.

Probst, J. L. and Suchet, P. A. (1992) Fluvial suspended sediment transport and mechanical erosion in the Maghreb (North Africa), Hydrological Sciences Journal 37(6), 621-636.

Tixeront, J. (1960) Les débits solides des cours d'eau d'Algérie et de Tunisie. Étude hydrologique. Série II. Secrétariat agricole. Tunis. Hydrological Sciences Journal 53, 26-41.

Touaibia, B. (2000) Érosion - Transport Solide - Envasement de barrage : Cas du bassin versant de l'Oued Mina - Wilaya de Rélizane. Thèse de Doctorat d'Etat en Science Agronomique. Institut Nationale Agronomique INA, El Harrach, Alger. Algérie 175.

Touaibia, I. (2013) Débit pluvial et érosion spécifique: Quantification en absence de jaugeages dans une zone sujette aux inondations Wilaya de Tipasa. Mémoire de Magistére. Université Abou Bakr Belkaid Tlemcen. 115.

Wischmeier, W. H and Smith, D. D. (1978) Predicting rainfall erosion losses. Guide to conservation planning. USDA-ARS, Agriculture Handbook n537. Washington. 58. 